\title{
Francisco Lafarga, Traducciones españolas de Victor Hugo. Repertorio bibliográfico
}

\section{Marco Stupazzoni}

\section{(2) OpenEdition}

1 Journals

\section{Edizione digitale}

URL: https://journals.openedition.org/studifrancesi/46095

DOI: 10.4000/studifrancesi.46095

ISSN: 2421-5856

\section{Editore}

Rosenberg \& Sellier

\section{Edizione cartacea}

Data di pubblicazione: 1 octobre 2007

Paginazione: 466

ISSN: 0039-2944

\section{Notizia bibliografica digitale}

Marco Stupazzoni, «Francisco Lafarga, Traducciones españolas de Victor Hugo. Repertorio bibliográfico», Studi Francesi [Online], 152 (LI | II) | 2007, online dal 30 novembre 2015, consultato il 24 novembre 2021. URL: http://journals.openedition.org/studifrancesi/46095 ; DOI: https://doi.org/10.4000/ studifrancesi.46095

Questo documento è stato generato automaticamente il 24 novembre 2021.

\section{(c)}

Studi Francesi è distribuita con Licenza Creative Commons Attribuzione - Non commerciale - Non opere derivate 4.0 Internazionale. 


\title{
Francisco Lafarga, Traducciones españolas de Victor Hugo. Repertorio bibliográfico
}

\author{
Marco Stupazzoni
}

\section{NOTIZIA}

FRANCISCO LAFARGA, Traducciones españolas de Victor Hugo. Repertorio bibliográfico, Barcelona, P.P.U., 2002, pp. 134.

1 Le celebrazioni del bicentenario della nascita di Victor Hugo hanno coinciso, in Spagna, con la pubblicazione di questa utile e interessante bibliografia delle traduzioni delle opere dello scrittore francese edite in terra iberica, curata per l'occasione da Francisco Lafarga. Questo repertorio bibliografico ha senza alcun dubbio il merito di colmare una lacuna nel panorama degli studi sulla ricezione editoriale del nostro autore. Il volume si struttura in due sezioni fondamentali: nella prima, è riportata la trascrizione bibliografica delle diverse edizioni delle opere complete e delle raccolte di opere scelte che dalla seconda metà dell'Ottocento si sono succedute fino ai giorni nostri (pp. 23-42). Nella seconda (pp. 43-120), l'A. registra con attenzione le traduzioni dei singoli testi hugoliani: nel fittissimo panorama delle opere poetiche, romanzesche, teatrali e critiche, primeggiano su tutte Notre-Dame de Paris (118 riferimenti) e Les Misérables (105) seguite, a considerevole distanza, da Quatre-vingt-treize (35), Bug-Jargal (29), Han d'Islande (21) ed Hernani (20). 